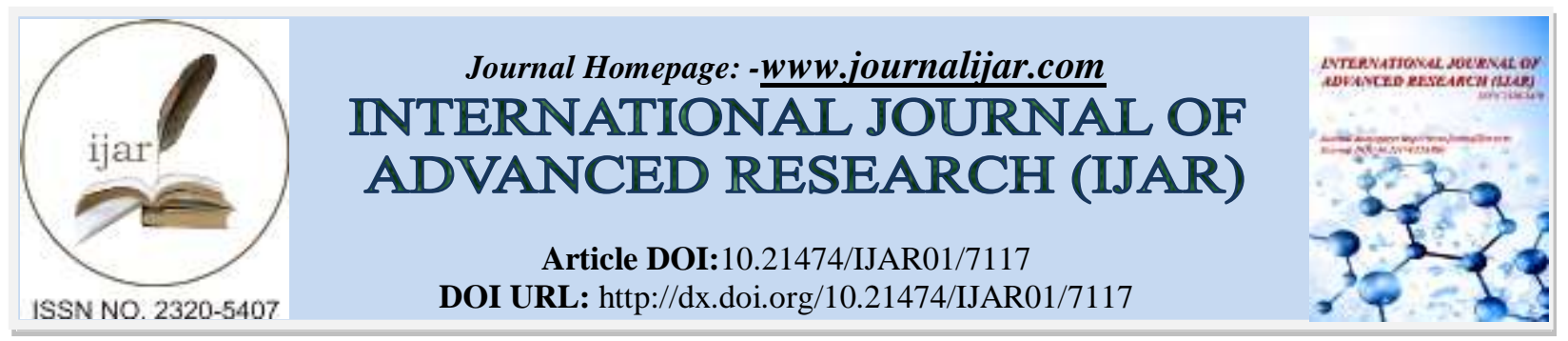

RESEARCH ARTICLE

\title{
INCIDENCE AND DISTRIBUTION OF DOWNY MILDEW DISEASE (PERONOSCLEROSPORA SORGHI) OF SORGHUM IN UGANDA.
}

\section{Kumi Frank ${ }^{1,2}$, Agbahoungba Symphorien ${ }^{1}$, Badji Arfang ${ }^{1}$, Odong Thomas ${ }^{1}$, Edema Richard ${ }^{1}$, Ochwo-} Ssemakula Mildred ${ }^{1}$, Nakubulwa Dianah ${ }^{1}$, Tusiime Geoffrey ${ }^{1}$, Biruma Moses ${ }^{3}$ and Rubaihayo Patrick ${ }^{1}$.

1. Department of Agricultural Production, College of Agricultural and Environmental Sciences, Makerere University, P.O. Box 7062, Kampala, Uganda.

2. Department of Crop Science, College of Agricultural and Natural Sciences, University of Cape Coast, P.M.B Cape Coast, Ghana.

3. National Semi-Arid Resources Research Institute (NaSARRI), Serere, Uganda.

\section{Manuscript Info}

[.........................

Manuscript History

Received: 16 March 2018

Final Accepted: 18 April 2018

Published: May 2018

Keywords:-

Conidia, incidence, severity, resistance, multiple linear regression, chi-square.

\section{Abstract}

Sorghum (Sorghum bicolor) ranks as the third most important staple cereal food crop in Uganda after maize and millet. The crop is hampered by several biotic stresses of which Sorghum Downy Mildew disease is one of the most devastating diseases. The disease is caused by a soil-borne fungus Peronosclerospora sorghi but it is also air-borne through conidia. Incidence and severity of downy mildew were conducted between March-June, 2016 and September-December 2016 growing seasons in 13 sorghum-growing districts across ten agroecological zones. Data collected were subjected to analyses of variance, correlation and linear regression. Significant $(P<0.001)$ differences were recorded for disease incidence and severity across the different agro-ecologies. The mean downy mildew disease incidence varied significantly $(\mathrm{P}<0.001)$ from $49.4 \%$ for Pader to $78.9 \%$ for Namutumba. Disease severity varied significantly $(\mathrm{P}<0.001)$ from 2.3 for Pader to 3.5 for Pallisa. Chi-square test for independent association between cropping season and downy mildew disease incidence showed a high significant test statistic values $(\chi 2=140.89$, d.f $=3$, and $\mathrm{P}<$ 0.001). A significant $(\mathrm{P}<0.001)$ positive correlation was observed between disease incidence and severity $(r=0.498)$ while a significant negative correlation was observed between disease incidence and rainfall $(r=-0.675)$ due largely to temperature and relative humidity. Multiple linear regression analysis revealed that temperature, relative humidity, rainfall and altitude explained $49 \%$ of the total variation associated to disease incidence. Variations in the incidence and severity of downy mildew disease prompt the need to screen for resistant/tolerant sorghum varieties.

Copy Right, IJAR, 2018,. All rights reserved. 


\section{Introduction:-}

Sorghum (Sorghum bicolor [L.] Moench) is the world's fifth major cereal after Maize, Wheat, Rice and Barley in terms of worldwide production and acreage (FAO, 2013). It is a staple food crop for millions of the poorest and most food-insecure people in the semi-arid tropics of Africa, Asia and Central America (Revy et al., 2010). It is grown on a total land area of 47 million ha worldwide, with annual yield of 69 million tons of grain, of which Africa produces about 20 million tonnes (FAOSTAT, 2013). An average of $1.45 \mathrm{t} / \mathrm{ha}$ productivity has been reported in Uganda (FAOSTAT, 2013). Sorghum is crucially important to food security in Africa, as it is genetically adapted to drought where other crops like maize, rice and wheat may not survive (Patanè et al., 2012). Sorghum can also withstand periods of high temperatures and to some extent, waterlog (Promkhambut et al., 2010). In Uganda, sorghum ranks as the third most important staple cereal food crop after maize and millet occupying over 400,000 ha of the total arable land with a yield of 380,000 metric tonnes (UBOS, 2010). It is still largely grown as a subsistence food crop in the Northern, Eastern and Western regions of Uganda but recently, it has increasingly been demanded for food and beverage industries (Rao et al., 2015; Datta et al., 2012).

The production of sorghum and its yield are constrained by a myriad of biotic and abiotic factors (Jeger et al., 1998) with Sorghum Downy Mildew (SDM) (Penorosclerospora sorghi) being one of the most devastating biotic stresses (Jeger et al., 1998). The disease is characterized by different pathotypes with unique symptoms (Thakur and Pande, 1995). Infected seedlings become stunted and chlorotic with infected young plants likely to die (Jeger, 1998). Older leaves may exhibit alternating parallel stripes of green and yellowish-green to white tissue. Under cool and humid conditions a white downy growth is produced on the lower leaf surface. The chlorotic tissue stripes eventually die and leaves become shredded. Heads produced on these plants may be fully or partially seedless (Jeger et al., 1998). Globally, SDM affected areas experience significant economic losses as high as 50\%-100\%. These loses occur in tropical lowland, subtropical, mid-altitude, and highland environments when the disease is left uncontrolled (Jeffers et al., 2000). Although empirical information on distribution of SDM in sorghum is limited in Uganda, reports on severity and distribution are available from neighboring countries of Kenya (Ngugi et al., 2002, EPPO, 2014) and Tanzania and Burundi (EPPO, 2014). Limited information and research on the disease coupled with farmers' lack of knowledge in the preventive and control mechanisms of the disease poses a severe threat to the production of the crop. This paper reports the incidence, severity and distribution pattern of SDM disease of sorghum in the different major sorghum growing districts in Uganda.

\section{Methodology:-}

\section{Sampling areas and sampling method:-}

Field surveys were conducted for two seasons (March-June, 2016; major growing season and September-December 2016 minor growing season) for disease incidence and severity of Sorghum Downy Mildew. In all thirteen major sorghum growing districts from ten agro-ecological zones (Wortmann and Eledu, 1999) were surveyed (Table 1). These agro-ecologies are well differentiated by farming systems, soil factors, weather and climatic conditions, altitude and the prevailing vegetation cover. These agro-ecologies and their respective $\operatorname{district}(\mathrm{s})$ (Fig 1) were selected purposively (Tongco, 2007) for the economic and livelihood significance derived from sorghum in these areas. Twenty sorghum farms were randomly selected from each district. A total of 10 districts out of the 13 districts were surveyed during the first season (due to drought incidence recorded in Lira, Pader and Serere).

Table 1:-Surveyed districts and their respective agro-ecological zones for sorghum downy mildew disease in Uganda.

\begin{tabular}{|l|c|c|c|l|l|}
\hline District & $\begin{array}{c}\text { Altitude } \\
(\mathrm{m})\end{array}$ & $\begin{array}{c}\text { Ave. } \\
\text { Temp } \\
(\mathrm{C})\end{array}$ & $\begin{array}{c}\text { Annual } \\
\text { Rainfall } \\
(\mathrm{mm})\end{array}$ & $\begin{array}{l}\text { Agro-ecological } \\
\text { zone }\end{array}$ & Description of vegetation \\
\hline Iganga & 1022 & 22.3 & 1313 & $\begin{array}{l}\text { Lake Victoria } \\
\text { Crescent }\end{array}$ & $\begin{array}{l}\text { Mainly isolated forest savanna and } \\
\text { grassland }\end{array}$ \\
\hline Namutumba & 1091 & 23.4 & 1011 & $\begin{array}{l}\text { Lake Victoria } \\
\text { Crescent }\end{array}$ & Wetlands, forest savanna and shrubs \\
\hline Pallisa & 1081 & 23.2 & 1353 & Lake Kyoga Basin & $\begin{array}{l}\text { Mainly forest savanna and riparian } \\
\text { patches }\end{array}$ \\
\hline Kumi & 1125 & 23.2 & 1238 & Lake Kyoga Basin & $\begin{array}{l}\text { Forest savanna, grassland and riparian } \\
\text { spots }\end{array}$ \\
\hline
\end{tabular}




\begin{tabular}{|l|c|c|c|l|l|}
\hline Serere & 1104 & 23.8 & 1362 & Eastern Highlands & $\begin{array}{l}\text { Classified as wooded savanna, forest } \\
\text { savanna, grassland and riparian. }\end{array}$ \\
\hline Lira & 1153 & 23.6 & 1219 & Northern Grassland & Forest savanna, grassland and swamps \\
\hline Pader & 979 & 23.7 & 1239 & Northern Grassland & $\begin{array}{l}\text { Woody savanna, grassland and } \\
\text { swamps }\end{array}$ \\
\hline Hoima & 1113 & 22.6 & 1382 & $\begin{array}{l}\text { Western Mid- } \\
\text { Altitude }\end{array}$ & $\begin{array}{l}\text { Broadly classified into forest, } \\
\text { savannah, grassland and swamps }\end{array}$ \\
\hline Masindi & 1194 & 22.9 & 1355 & $\begin{array}{l}\text { Lake Albert } \\
\text { Crescent }\end{array}$ & $\begin{array}{l}\text { Five broad categories of vegetation are } \\
\text { classified; tropical forests, savannah } \\
\text { grassland and savanna woodland, } \\
\text { permanent and seasonal swamps }\end{array}$ \\
\hline Arua & 1109 & 22.9 & 1404 & West Nile & $\begin{array}{l}\text { Predominantly savanna (mixed } \\
\text { wooded and grassland) with others } \\
\text { classifications such as forest and } \\
\text { wetland. }\end{array}$ \\
\hline Nebbi & 1061 & 23.2 & 1098 & $\begin{array}{l}\text { Northwestern } \\
\text { Grassland }\end{array}$ & $\begin{array}{l}\text { Consist of savanna (woodland, } \\
\text { grassland) and shrubs }\end{array}$ \\
\hline Kabarole & 1106 & 19.3 & 1459 & $\begin{array}{l}\text { Western Mid-High } \\
\text { Altitude }\end{array}$ & $\begin{array}{l}\text { Characterized with wetlands, forest } \\
\text { and savanna woodland }\end{array}$ \\
\hline Kabale & 1934 & 17.2 & 1018 & $\begin{array}{l}\text { Southwestern } \\
\text { Highlands }\end{array}$ & $\begin{array}{l}\text { Three broad categories of vegetation } \\
\text { can be distinguished; high altitude } \\
\text { forest, forest savanna and swamp } \\
\text { forest }\end{array}$ \\
\hline
\end{tabular}




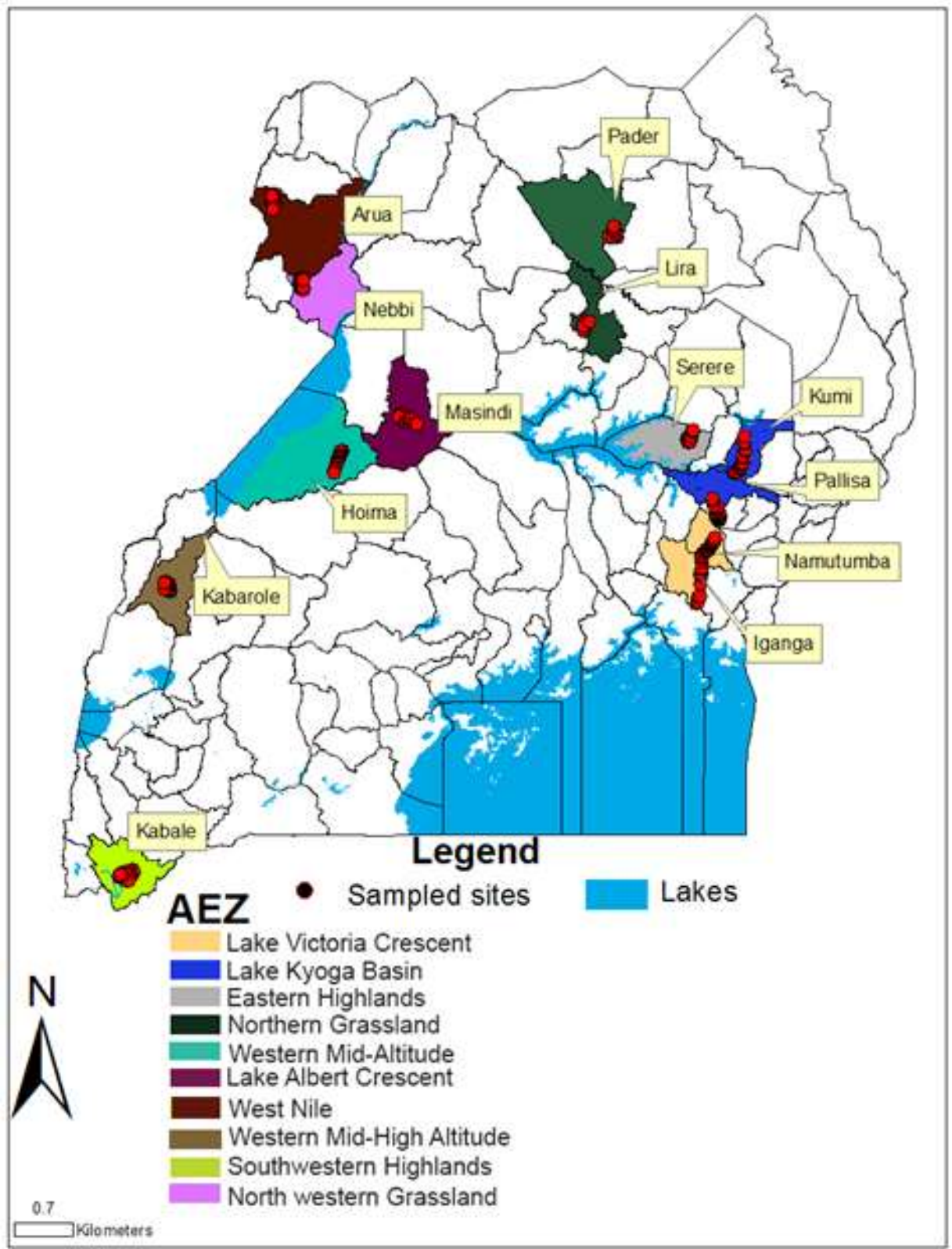

Fig 1:-Surveyed districts for downy mildew disease in 2016a (major season) and 2016b (minor season) in Uganda.

Source: (Wortmann and Eledu, 1999)

\section{Data collection and analyses:-}

A total of four hundred and sixty (460) sorghum farms, were randomly selected and assessed for SDM incidence and severities in the year 2016 for two seasons across ten AEZ in Uganda (Fig 1). Data were collected on the incidence and severity of SDM disease. In addition to the incidence and severity of SDM data, relative humidity, temperature, elevation above sea level and precipitation parameters were taken. Farms were selected at a minimum distance of 500 meters interval apart and the Global Positioning System (GPS) for altitude and co-ordinates were taken at each farm using a GPS receiver. In farmers' fields, SDM incidence was assessed based on percentage as described by Ward et al. (1999). A total of 50 sorghum plants were sampled from each farm and assessed for SDM using key symptoms such as leaf streaks, necrotic leaf, chlorosis, downy appearance, leaf shredding, stunted growth and vein clearing (Jeger et al., 1998). Plants showing SDM symptoms were counted and expressed as a proportion to the total number of plants assessed. Percentage disease incidence (PDI) was computed using the formula of Ward et al. (1997); 


$$
\mathrm{PDI}=\frac{\text { Number } \text { of plants infected }}{\text { Total number of plants }} \times 100
$$

Severity of SDM disease in the field was assessed using a quantitative scale adapted from Ward et al. (1999) which takes into account the percentage of the leaf area showing SDM symptoms, a scale of 1-5 where; $1=$ no symptoms on leaves, $2=1-25 \%$ leaf area infection, $3=26-50 \%$ leaf area infection, $4=51-75 \%$ and $5=76-100 \%$ leaf area infection.

Field incidence and severity data for SDM from all the surveyed sites were subjected to one-way analysis of variance (ANOVA) (Steel et al., 1997) at a probability level of 5\% using Genstat Statistical package version 15. Multiple Linear regression analysis was carried out using Genstat Statistical package. Disease incidence and severity were used as the dependent variables as against temperature, relative humidity, rainfall and altitude which were the independent variables. Arcsine transformation was used to transform SDM incidence scores which were in percentages before carrying out ANOVA. Data for SDM disease incidence and severity means were separated using Fisher's protected Least Significant Difference (LSD) test at $\mathrm{P}<0.05$ using Genstat statistical package version 15.

Chi-square test for independence or association of incidence and severity data with temperature range was done in Genstat using the maximum likelihood method. Correlation between incidence and severity was done using means. Disease incidence and severity score as well GPS coordinates of the respective sampling locations were used to generate SDM Disease map using Geographic Information Systems (GIS) Arc View 3.2 software.

\section{Results:-}

The results for the analysis of associated with downy mildew disease are presented in Table 2 . The result showed that, rainfall significantly affected $(\mathrm{P}<0.001)$ the incidence and severity of downy mildew disease.

Table 2:-Mean sum of squares for downy mildew disease incidence and severity in different districts under different agro-ecological zones in Uganda, 2016.

\begin{tabular}{|l|c|c|c|c|c|}
\hline & & \multicolumn{2}{|c|}{ Incidence } & \multicolumn{2}{c|}{ Severity } \\
\hline Source of variation & df & Mean ssquare & F. pr & Mean square & F. pr \\
\hline AEZ & 9 & $4054.3^{* * *}$ & $<0.001$ & $2.5274 * * *$ & $<0.001$ \\
\hline District & 12 & $655.7 * * *$ & $<0.001$ & $1.0992^{* * *}$ & $<0.001$ \\
\hline Rainfall & 1 & $57674.7 * * *$ & $<0.001$ & $29.3222^{* * *}$ & $<0.001$ \\
\hline District x Rainfall & 9 & $290.2^{* *}$ & $<0.001$ & $0.1951^{\text {NS }}$ & 0.244 \\
\hline Residual & 428 & 112.7 & & 0.1522 & \\
\hline
\end{tabular}

$\mathrm{AEZ}=$ Agro-ecological zone; NS = not significant; $* * *=$ significant at $\mathrm{P}<0.001$ and $* *=$ significant at $\mathrm{P}<0.01$.

The results also showed high significant differences $(\mathrm{P}<0.001)$ of downy mildew disease incidence and severity within Agro-ecological zones and districts. More so, the interaction between District x rainfall for disease incidence was significant $(\mathrm{P}<0.001)$ but the interaction between disease severity for District $\mathrm{x}$ rainfall showed no significant difference $(\mathrm{P}<0.001)$.

The results for downy mildew disease incidence and severity for the two growing seasons in 2016 are presented in Fig. 2. The results showed variations in disease incidence and severity across agro-ecological zones. The major season recorded mean downy mildew disease incidence ranged between 75 to $92 \%$ (Fig 2A). Arua district recorded the highest disease incidence $(92 \%)$ in the major season, while Kabarole district recorded the lowest disease incidence of $64 \%$ (Fig. 2A). Kabale, Kumi, Namutumba, Masindi and Pallisa districts all recorded a mean disease incidence greater than $81 \%$ while Nebbi, Hoima and Iganga districts recorded incidence less than $81 \%$ (Fig. 2A) in the major season.

In the minor season, similar variations for downy mildew disease incidence were recorded. The highest mean disease incidence was 68 \% (Fig. 2B), recorded in Namutumba district. Kabarole, Hoima, Lira, Iganga, Pader, and Serere districts all recorded mean disease incidence between 40 and $53 \%$ while Arua, Kabale, Masindi, Kumi, Nebbi and Pallisa districts recorded mean disease incidence between 54 and $67 \%$ in the minor season (Fig. 2B). 

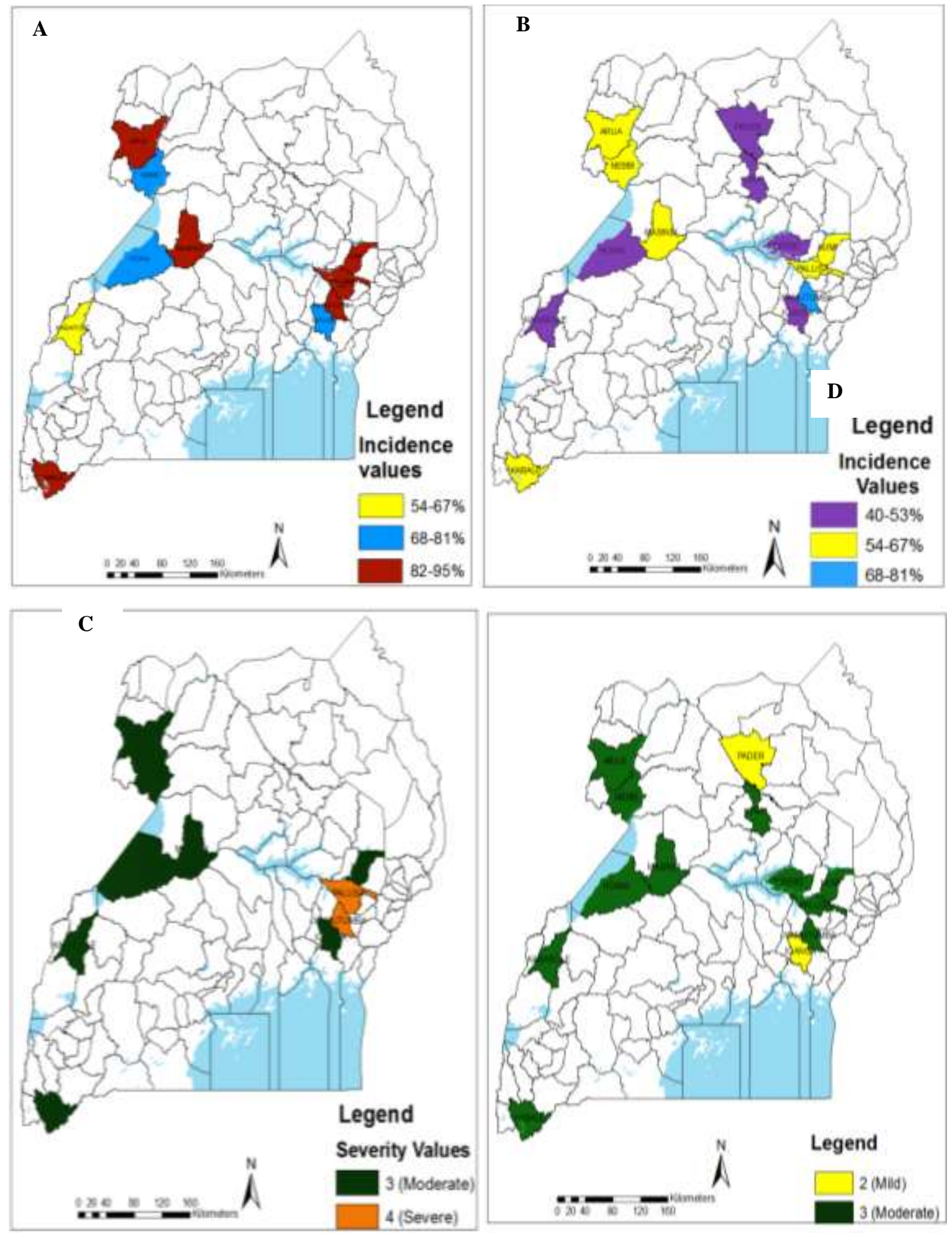

Fig. 2. A. Incidence of SDM disease in ten sorghum growing districts during 2016 major season (March-June) B. Incidence of SDM in thirteen sorghum growing districts during 2016 major season (September-December) C. Severity of SDM in ten sorghum growing districts during 2016 major season (March-June) D. Severity of SDM in thirteen sorghum growing districts during 2016 major season (September-December). 
Similarly, Downy mildew disease severity varied across districts for both seasons (Fig 2). The highest disease severity was recorded in the major season, with a severity score of 4 (Fig 2C) in Namutumba and Pallisa, while a severity score 4 (severe) was recorded in Namutumba and Pallisa while the remaining eight districts namely; Arua, Hoima, Iganga, Kabale, Kabarole, Kumi, Masindi and Nebbi all recorded a severity score 3 (moderate) in the major season (Fig. 2C). Conversely, the minor season recorded a lower disease severity score (Fig. 2D), with the highest severity score of 3 (moderate) recorded for Arua, Nebbi, Hoima, Masindi, Kabarole, Kabale, Lira, Serere, Kumi, Pallisa and Namutumba while Pader and Iganga districts recorded the lowest severity score in the minor season (Fig. 2D).

Downy mildew disease was found in all the sorghum fields which were surveyed (Table 3). Downy mildew disease was found in all the sorghum fields were the surveyed was carried out (Table 3). The mean incidence for downy mildew disease, varied significantly in a range of $49.4 \%$ (Pader) to $78.9 \%$ (Namutumba) with an average incidence of $65.3 \%$. The mean disease incidence for Pader (49.3\%), Lira (49.7\%) and Serere (53.3\%) were not significantly different from each other. However the incidence recorded in Arua (73.1\%), Kabale (75.6\%), Pallisa (77.5\%), Kumi $(78.8 \%)$ and Namutumba $(78.9 \%)$ varied significantly from the recorded mean disease incidence for Pader (49.4\%), Lira (49.7\%), Serere (53.3\%), Kabarole (55.3\%), Iganga (59.2\%), Hoima (60.4\%) and Nebbi (64.8\%). The disease severity varied significantly $(\mathrm{P}<0.001)$ amongst the surveyed agro-ecological zones. The lowest $(2.3)$ and the highest (3.5) severity scores were recorded in Pader and Pallisa respectively. Severity scores from Serere (2.8), Kabarole (2.8), Iganga (2.8), Hoima (2.9), Nebbi (2.8), Masindi (2.7), Kabale (2.9), and Kumi (2.9) were not significantly different from each other.

Pader recorded the lowest relative humidity $(46.0 \%)$ while Kabale recorded the highest relative humidity $(85.5 \%)$. The remaining districts however, recorded a relative humidity between the range of $47 \%-79 \%$. The maximum temperature recorded was in the range of $27-34{ }^{\circ} \mathrm{C}$.

Table 3:-Combined means for growing seasons for SDM disease incidence, severity and weather parameters in all districts and Agro-ecological zones.

\begin{tabular}{|c|c|c|c|c|c|c|c|}
\hline District & $\begin{array}{l}\text { Agro-ecological } \\
\text { zone }\end{array}$ & $\begin{array}{c}\text { Incide } \\
\text { nce }\end{array}$ & $\begin{array}{l}\text { Sever } \\
\text { ity }\end{array}$ & $\begin{array}{c}\text { Actual } \\
\text { Temp }\left({ }^{\circ} \mathrm{C}\right)\end{array}$ & $\begin{array}{l}\text { Minimum } \\
\text { Temp }\left({ }^{\circ} \mathrm{C}\right)\end{array}$ & $\begin{array}{l}\text { Maximum } \\
\text { Temp }\left({ }^{\circ} \mathrm{C}\right)\end{array}$ & $\begin{array}{c}\text { Relative } \\
\text { Humidity (\%) }\end{array}$ \\
\hline Pader & $\begin{array}{l}\text { Northern } \\
\text { Grassland }\end{array}$ & $49.4 \mathrm{a}$ & $2.3 \mathrm{a}$ & 22.6 & 18 & 34 & 46.0 \\
\hline Lira & $\begin{array}{l}\text { Northern } \\
\text { Grassland }\end{array}$ & $49.7 \mathrm{a}$ & $2.5 \mathrm{ab}$ & 23.1 & 18 & 33 & 47.0 \\
\hline Serere & Eastern Highlands & $\begin{array}{c}53.3 \mathrm{a} \\
\mathrm{b}\end{array}$ & $2.8 \mathrm{c}$ & 23.5 & 18 & 33 & 67.0 \\
\hline $\begin{array}{l}\text { Kabarol } \\
\text { e }\end{array}$ & $\begin{array}{l}\text { Western Mid-High } \\
\text { Altitude }\end{array}$ & $\begin{array}{c}55.3 b \\
c\end{array}$ & $2.8 \mathrm{c}$ & 22.3 & 14 & 27 & 70.0 \\
\hline Iganga & $\begin{array}{l}\text { Lake Victoria } \\
\text { Crescent }\end{array}$ & $\begin{array}{c}59.2 \mathrm{c} \\
\mathrm{d}\end{array}$ & $2.8 \mathrm{c}$ & 25.0 & 17 & 30 & 79.0 \\
\hline $\begin{array}{l}\text { Namutu } \\
\text { mba }\end{array}$ & $\begin{array}{l}\text { Lake Victoria } \\
\text { Crescent }\end{array}$ & $78.9 f g$ & 3.3ef & 23.9 & 18 & 31 & 78.0 \\
\hline Hoima & $\begin{array}{l}\text { Western Mid- } \\
\text { Altitude }\end{array}$ & $\begin{array}{c}60.4 \mathrm{c} \\
\mathrm{d}\end{array}$ & $2.9 \mathrm{~cd}$ & 23.0 & 18 & 31 & 67.0 \\
\hline Nebbi & $\begin{array}{l}\text { Northwestern } \\
\text { Grassland }\end{array}$ & $64.8 \mathrm{~d}$ & $2.8 \mathrm{c}$ & 23.6 & 18 & 32 & 57.5 \\
\hline Masindi & $\begin{array}{l}\text { Lake Albert } \\
\text { Crescent }\end{array}$ & $72.4 \mathrm{e}$ & $2.7 \mathrm{bc}$ & 22.7 & 18 & 31 & 69.0 \\
\hline Arua & West Nile & 73.1ef & $3.1 \mathrm{de}$ & 24.4 & 18 & 31 & 58.5 \\
\hline Kabale & $\begin{array}{l}\text { Southwestern } \\
\text { Highlands }\end{array}$ & 75.6ef & $2.9 \mathrm{~cd}$ & 20.0 & 12 & 24 & 85.5 \\
\hline Pallisa & Lake Kyoga Basin & 77.5ef & $3.5 \mathrm{f}$ & 22.6 & 18 & 32 & 73.5 \\
\hline Kumi & Lake Kyoga Basin & $78.8 \mathrm{fg}$ & $2.9 \mathrm{~cd}$ & 22.6 & 18 & 32 & 64.0 \\
\hline Std dev & & 11.3 & 0.3 & 1.2 & 1.9 & 2.7 & 11.8 \\
\hline
\end{tabular}




\begin{tabular}{|l|l|c|c|c|c|c|c|}
\hline CV \% & & 17 & 13.8 & 5.2 & 11.1 & 8.7 & 17.8 \\
\hline Lsd & & 5.8 & 0.2 & 0.3 & & & \\
\hline
\end{tabular}

Mean values with the same alphabet within a column are not significantly different $(\mathrm{P}<0.05)$; $\mathrm{CV}=$ coefficient of variation; Lsd $=$ Least significant difference, $\operatorname{Std} \operatorname{dev}=$ Standard deviation, Temp $=$ Temperature

Results of chi-square test for independent association to test the null hypothesis that incidence of downy mildew disease is independent of cropping season are presented in Table 4. The results showed a highly significant test statistic values $(\chi 2=225.89$, d.f $=3$, and $\mathrm{P}<0.001)$.

Table 4:-Combined chi-sqaure test for downy mildew disease incidence and severity.

\begin{tabular}{|c|c|c|c|c|c|c|c|c|c|c|}
\hline \multirow{2}{*}{$\begin{array}{l}\text { Cropping } \\
\text { Season }\end{array}$} & \multicolumn{5}{|c|}{ Incidence } & \multicolumn{5}{|c|}{ Severity } \\
\hline & Low & Moderate & High & $\begin{array}{l}\text { Very } \\
\text { high }\end{array}$ & Margin & Low & Mild & Severe & $\begin{array}{l}\text { Very } \\
\text { severe }\end{array}$ & Margin \\
\hline Major & 46.96 & 4.47 & 0.06 & 76.18 & 127.68 & 0.43 & 47.31 & 17.53 & 14.36 & 79.64 \\
\hline Minor & 36.13 & 3.44 & 0.05 & 58.60 & 98.21 & 0.33 & 36.39 & 13.49 & 11.05 & 61.26 \\
\hline Margin & 83.09 & 7.91 & 0.11 & 134.78 & 225.89 & 0.77 & 83.70 & 31.02 & 25.41 & 140.89 \\
\hline$\chi^{2}$ & & & 225.8 & & & & & 140 & & \\
\hline $\mathrm{Df}$ & & & 3 & & & & & 3 & & \\
\hline $\mathrm{P}$ value & & & $<0.00$ & & & & & $<0$. & & \\
\hline
\end{tabular}

Major cropping season alone contributed 127.68 margin to the chi-square statistic of 225.89 while incidence level rated as very high contributed a margin of 76.18. The chi-square test for independent association of disease severity from cropping season showed the test statistic values $\left(\chi^{2}=140.89\right.$, d.f $=3$, and $\left.\mathrm{P}<0.001\right)$. Major cropping season contributed 79.64 margin to the chi-square statistic of 140.89 , and 14.36 was contributed by severity level rated as very severe.

The analysis of variance associated with the multiple linear regression performed between downy mildew disease incidence, weather parameters (relative humidity, rainfall and temperature) and altitude showed a high significant difference $(\mathrm{P}<0.001)$ (Table 5).

Table 5:-Combined mean sum of squares associated with linear regression of downy mildew disease incidence, disease severity, weather parameter and altitude in 13 districts in Uganda, 2016.

\begin{tabular}{|l|c|c|c|}
\hline \multicolumn{1}{|c|}{ Source of variation } & Degree of freedom & Incidence & Severity \\
\hline Regression & 4 & $18879.5^{* * *}$ & $10.74^{* * *}$ \\
\hline Residual & 455 & 172.8 & 0.20 \\
\hline Total & 459 & 335.8 & 0.29 \\
\hline & $\mathrm{R}^{2}$ & 0.49 & 0.32 \\
\hline
\end{tabular}

*** Significant at $P<0.001$

Similarly, multiple linear regression between downy mildew disease severity, weather parameters (relative humidity, rainfall and temperature $)$ and altitude showed a high significant difference $(\mathrm{P}<0.001)$. The associated coefficient of determination $\left(\mathrm{R}^{2}\right)$ for incidence and severity of downy mildew disease were 0.49 and 0.32 respectively.

Wald test results showed a significant difference $(\mathrm{P}<0.001)$ for disease incidence and severity against all the parameters measured (Table 6).

Table 6:-Estimates of parameters of linear regression downy mildew disease incidence against weather parameters and altitude

\begin{tabular}{|l|c|c|c|c|c|}
\hline Parameters & Estimates & Standard error & $\mathrm{t}(455)$ & Wald statistic & F pr. \\
\hline \multicolumn{5}{|c|}{ Disease Incidence } \\
\hline Constant & 146.40 & 16.000 & 9.17 & - & $<0.001$ \\
\hline Temperature $\left({ }^{\circ} \mathrm{C}\right)$ & $-2.260^{* * *}$ & 0.573 & -3.94 & 15.54 & $<0.001$ \\
\hline Rel. humidity $(\%)$ & $0.300^{* * *}$ & 0.073 & 4.08 & 16.68 & $<0.001$ \\
\hline Rainfall $(\mathrm{mm})$ & $20.510^{* * *}$ & 1.510 & -13.57 & 184.05 & $<0.001$ \\
\hline
\end{tabular}




\begin{tabular}{|l|c|c|c|c|c|}
\hline Altitude (m) & $-0.030 * * *$ & 0.004 & -3.61 & 13.02 & $<0.001$ \\
\hline \multicolumn{5}{|c|}{ Disease Severity } \\
\hline Constant & 4.237 & 0.538 & 7.88 & - & $<0.001$ \\
\hline Temperature $\left({ }^{\circ} \mathrm{C}\right)$ & $-0.035^{* * *}$ & 0.019 & -1.80 & 3.25 & 0.072 \\
\hline Rel. humidity (\%) & $0.011^{* * *}$ & 0.002 & 4.47 & 19.95 & $<0.001$ \\
\hline Rainfall (mm) & $-0.446^{* * *}$ & 0.510 & -8.76 & 76.72 & $<0.001$ \\
\hline Altitude (m) & $-0.001 * * *$ & 0.001 & -4.16 & 17.31 & $<0.001$ \\
\hline
\end{tabular}

*** significant at $P<0.001$

The Wald test estimates for disease incidence recorded significant regression coefficient values of $-2.26,0.30,20.51$ and -0.03 for temperature, relative humidity, rainfall and altitude respectively. Severity also recorded a significant regression coefficient values of $-0.035,0.011,-0.446$ and -0.001 for temperature, relative humidity, rainfall and altitude respectively.

Correlations were run to compare parameters associated to downy mildew disease and the results showed significant differences (Table 7).

Table 7:-Correlation coefficients between downy mildew disease (incidence and severity), weather parameters and altitude in 2016 growing seasons.

\begin{tabular}{|c|c|c|c|c|c|c|}
\hline Parameters & Incidence $(\%)$ & Severity score & Temp $\left({ }^{\circ} \mathrm{C}\right)$ & $\begin{array}{l}\text { Rel.Hum } \\
(\%)\end{array}$ & Rainfall (mm) & $\begin{array}{c}\text { Altitude } \\
\text { (m) }\end{array}$ \\
\hline Incidence $(\%)$ & - & & & & & \\
\hline Severity score & $0.498 * * *$ & - & & & & \\
\hline Temp $\left({ }^{\circ} \mathrm{C}\right)$ & $-0.242 * * *$ & $-0.109 *$ & - & & & \\
\hline Rel.Hum (\%) & $0.445 * * *$ & $0.365 * * *$ & $-0.344 * * *$ & - & & \\
\hline Rainfall (mm) & $-0.675 * * *$ & $-0.536 * * *$ & $0.206 * * *$ & $-0.509 * * *$ & - & \\
\hline Altitude (m) & 0.058 & -0.038 & $-0.635 * * *$ & $0.474 * * *$ & -0.063 & - \\
\hline
\end{tabular}

Temp $=$ Temperature, Rel. Hum $=$ Relative Humidity, $* * *, *=$ significant at $\mathrm{P}<0.001$ and 0.05 .

The correlation coefficients showed that downy mildew disease incidence was significantly positively correlated with disease severity (0.498) and also positively correlated to relative humidity (0.445) and altitude (0.058). However, disease incidence was negatively correlated with rainfall $(-0.675)$ and temperature $(-0.242)$. Disease severity was significantly negatively correlated with temperature (-0.109), rainfall (-0.536) and altitude (-0.038) but correlated positively with relative humidity $(0.365)$. Temperature correlated negatively with relative humidity ($0.344)$ and altitude $(-0.635)$ but correlated positively correlated with rainfall $(0.206)$.

\section{Discussion:-}

Downy mildew disease was widely distributed in all the surveyed districts and fields at varying levels of disease incidence and severity and cropping season. In this study, disease incidence and severity recorded in the major season was higher than the incidence and severity recorded in the minor season. This variation could be attributed to the differences in the environmental factors (rainfall, temperature, relative humidity) which prevailed in different seasons as reported by Bigirwa et al., (2000). Bigirwa et al. (1998) and Adipala et al. (1999) reported low prevalence of downy mildew disease with $10 \%$ disease incidence (Bigirwa et al. 1998) with isolated distribution pattern of the disease for different cropping seasons. Similarly, low impact of the disease was reported in Nigeria (Ngugi et al., 2002), Zimbabwe, Zambia, Mozambique and Rwanda (Bock et al., 1998; Bock and Jeger, 1999). Contrary to these earlier reports on the disease distribution and prevalence (EPPO, 2014), this study however showed a significantly high disease incidence and severity pattern with a wider distribution pattern across ten agroecological zones. These variations could be attributed to the different environmental factors in the different agroecological zones (Bigirwa et al. 1998), cropping pattern (Kutama et al., 2010) and growing of susceptible cultivars (Wang et al., 2000).

However, this The results from the study also showed a significant dependent association between disease incidence, severity and cropping season and this explains the variations which were seen recorded for major and minor seasons. This confirms the seasonal variations of the SDM disease as reported by Bock et al., (1998). The study showed significant varying temperatures within the range of $20-25{ }^{\circ} \mathrm{C}$ for the ten different agro-ecological zones, reported 
Bock et al. (1998) to favour downy mildew conidia production, infection and subsequent epidemic development. High humidity accompanied with with an optimum temperature of $21-22{ }^{\circ} \mathrm{C}$ favours conidia development (Wang et al., 2000). Bock et al. (1998), reported that no conidia sporulation occurred at temperature $<13{ }^{\circ} \mathrm{C}$ or $>30{ }^{\circ} \mathrm{C}$, which therefore explains why the disease was therefore more prevalent in the various growing areas and showed a variation in the disease incidence and severity for the different agro-ecological zones.

Downy mildew disease was found in all the sorghum fields were the surveyed was carried out. Results showed that increased maximum, minimum temperatures and decrease in relative humidity reduced infection of downy mildew disease in Pader, Lira and Nebbi districts. The results further showed that low maximum, minimum temperatures and increased relative humidity favoured infection of downy mildew disease in Hoima, Iganga, Kabale, Kabarole, Kumi, Masindi, Namutumba and Pallisa districts. Infection was also observed to favoured by increased in areas of high precipitation (1011 - $1404 \mathrm{~mm}$ ) and altitude (>1000 m); this was evident in Kabale, Kabarole, Hoima, Masindi Pallisa and Namutumba districts which recorded both high disease incidence and severity. The study agreed with Kutama et al. (2010), Ngugi et al., (2002) and Bigirwa et al., (1998) who reported high prevalence of SDM in highlands and wetter areas in Nigeria, Kenya and Uganda (Hulluka and Esele, 1992). Previous report by Wang et al., (2000) and Bigirwa et al. (1998) and also showed that SDM is prevalent in highlands associated with cool temperatures with high relative humidity. .

Seasonal variations of the disease incidence and severity were also observed in this study and were significantly higher in the major cropping season compared to the minor cropping season due to favourable climatic conditions such as (relative humidity, temperature, rainfall) during the major cropping season as opposed to unfavourable factors (climatic and edaphic) during the minor cropping season (King and Mukuru, 1994). Similar results were reported Bock et al., (1998), that rainfall, suitable night-time temperatures and high relative humidity are required to allow conidia production, infection and subsequent epidemic development the disease. The differences in the disease patterns for agro-ecological zones could also be attributed to other factors which may have contributed to the high disease incidence and severity in the study areas are; mixed cropping which mainly included alternate host plants (maize, sugarcane) and exchange of diseased seeds amongst farmers (Thakur and Mathur, 2002).

There were both positive and negative relationships between weather parameters and altitude on SDM disease incidence and severity. There was a significantly positive disease incidence correlation with disease severity suggests that areas which recorded high disease incidence recorded a similar also in disease severity. The coefficient of determination $\left(\mathrm{R}^{2}\right)$ explained that $49 \%$ disease incidence and $32 \%$ disease index were associated with weather parameters and altitude. These findings agreed with Barbosa et al. (2006) who reported positive significant relationship between cumulative rainfall, relative humidity, temperature and disease incidence and severity of SDM. More so, significantly negative correlations between maximum temperature and disease incidence and severity suggests high temperature negatively affects the proliferation of the disease infection and epidemic (Sharma et al., 2010)

Similar findings were reported by Shawa and Osborne (2011) and Bock et al. (1998) on the response of disease prevalence to favourable climatic conditions. Their finding was that high optimum temperature $\left(20-23{ }^{\circ} \mathrm{C}\right)$ favours the germination and germ tube growth for disease infection. The trend reflected in this study, were Iganga, Hoima, Kabale, Kabarole, Kumi, Namutumba and Pallisa districts which recorded high relative humidity with a low temperature $\left(<33{ }^{\circ} \mathrm{C}\right)$ and recorded high disease incidence and severity. Wang et al. (2000), reported in Australia and Bock et al. (2002) reported in Zimbabwe that high relative humidity is a predictive determinant factor for downy mildew disease prevalence. This study further found negative significant correlation coefficients between rainfall and incidence and severity of the disease, which suggests that the affect of rainfall had a marked effect in the occurrence and spread of the disease (Thomas, 1992). Kutama et al., (2010) and Bock and Jeger (1999) also reported that adequate rainfall is needed for conidia production, infection and subsequent epidemic development.

This study showed that SDM was widespread in all the ten agro-ecologies the survey was carried out. Screening for sources of resistance to the disease will be for managing the disease threshold.

\section{Conclusion:-}

Downy mildew disease was prevalent and widely distributed in all the surveyed farms at varying incidence and severity levels. Among other factors, weather factors (temperature, relative humidity and rainfall) and altitude were 
significant in the spread of the disease in sorghum. There is a need for successive assessments of the disease spread in all sorghum growing areas over time and further identify sources of resistance to the disease in Uganda.

\section{Acknowledgements:-}

This research was funded by Carnegie Cooperation of New York through the Regional Universities Forum for Capacity Building in Agriculture (RUFORUM). National Semi-Arid Resources Research Institute (NaSARRI) Sorghum project provided logistical support during the disease survey and the extension workers and farmers for facilitated the research.

\section{References:-}

1. Adipala, E., Bigirwa, G., Esele, J. P. and Cardwell K. F. (1999). Development of sorghum downy mildew on sequential plantings of maize in Uganda. International Journal of Pest Management, 45(2):147-153.

2. Barbosa, F. C. R., Pfenning, L. H. and Casela C. R. (2006). Peronosclerospora sorghi, the causal agent of sorghum downy mildew. (Peronosclerospora sorghi, o agente etiológico do míldio do sorgo.) Fitopatologia Brasileira, 31(2):119-132.

3. Bigirwa, G., Adipala, E., and Esele, J. P., (1998). Occurrence of Peronosclerospora sorghi in Uganda. Plant Diseases. 82:757-760.

4. Bigirwa, G., Adipala, E., Esele, J. P. and Cardwell, K. F. (2000). Reaction of maize, sorghum and Johnson grass to Peronosclerospora sorghi. International Journal of Pest Management, 46(1):1-6.

5. Bock C. H., Jeger M. J., Mughogho, L. K., Cardwell, K. F. and Mtisi, E. (1999). Effect of dew point temperature and conidium age on germination, germ tube growth and infection of maize and sorghum by Peronosclerospora sorghi. Mycological Research, 103(7):859-864.

6. Bock, C. H. and Jeger, M. J. (1999). The effect of sowing date on the incidence of sorghum downy mildew on sorghum in Zimbabwe. Tropical Science, 39(4):194-203.

7. Bock, C. H., Jeger, M. J., Mughoho, L. K., Cardwell, K. F., Adenle, V., Mtisi, E., Akpa, A. D., Kaula, G., Mukasambina, D. and Blair-Myers C, (1998). Occurrence and distribution of Peronosclerospora sorghi (Weston and Uppal (Shaw)) in selected countries of West and Southern Africa. Crop Protection, 17(5):427-439.

8. Datta, M. S., Poshadri A., Srinivasa R. P,, Ravinder R. C. and Reddy B.V. S. (2012). Innovative use of sweet sorghum juice in the beverage industry. International Food Research Journal 19(4):1361-1366.

9. EPPO (2014). PQR database. Paris, France: European and Mediterranean Plant Protection Organization. http://www.eppo.int/DATABASES/pqr/pqr.htm

10. FAOSTAT (Food and Agriculture Organization of the United Nations). (2013). Production statistics: crops. FAO statistical databases, http://www.fao.org/faostat/en/\#data/QC

11. Hulluka, M., and Esele, J. P. E. (1992). Sorghum diseases in Eastern Africa. Pages 21-24 In: Sorghum and Millets Diseases: A Second World Review. W. J. A. de Milliano, R. A. Frederiksen, and G. D. Bergston, eds. ICRISAT, Patancheru, India.

12. Jeger M. J, Gilijamsea E, Bock C. H, Frinkinga H. D., (1998). The epidemiology, variability and control of the downy mildews of pearl millet and sorghum, with particular reference to Africa. Plant Pathology, 47:544-569.

13. Jeger, M. J. (1998). The effect of sowing date on the incidence of sorghum downy mildew in Zimbabwe, Tropical Science. 39: 194-203.

14. King, S. B. and Mukuru, S. Z. (1994). An overview of sorghum, finger millet and pearl millet in eastern Africa with special attention to diseases. Pages 24-34 in: Breeding for Disease Resistance with Emphasis on Duarability. D. L. Danial, ed. Wageningen Agricultural University, Wageningen, The Netherlands.

15. Kutama, A. S., Aliyu, B. S. and Emechebe, A. M, (2010). State of sorghum downy mildew in maize in the Sudan and Sahel savanna agro-ecological zones of Nigeria. Bayero Journal of Pure and Applied Sciences, 3(1):233-237.

16. Ngugi H. K., King S. B., Abayo G. O. and Reddy Y. V. R. (2002). Prevalence, incidence, and severity of sorghum diseases in western Kenya. Plant Disease 86, 65-70.

17. Patanè, C., and Saita, A., and Sortino, O. (2012). Comparative Effects of Salt and Water Stress on Seed Germination and Early Embryo Growth in Two Cultivars of Sweet Sorghum. Journal of Agronomy and Crop Science. 199. doi 10.1111/j.1439-037X.2012.00531.x

18. Promkhambut, A., Younger A., Polthanee A. and Akkasaeng C. (2010). Morphological and physiological responses of sorghum [(Sorghum bicolor L.) Moench] to waterlogging. Asian J. Plant Sci. 9, 183-193.

19. Rao P. S., Kumar C. G., Prakasham R. S., and Rao A. U., Reddy B. V. S. (2015) Sweet Sorghum: Breeding and Bioproducts. In: Cruz V.M.V., Dierig D.A. (eds) Industrial Crops. Handbook of Plant Breeding, vol 9. Springer, 
New York, NY.

20. Reddy, B. V. S., Ashok K. A. and Sanjana R. P. (2010). Recent advances in sorghum improvement research at ICRISAT. Kasetsart Journal (Natural Science) 44:499-506.

21. Sharma R., Rao V. P., Upadhyaya H.D , Reddy V. G. and Thakur R. P. (2010) Resistance to grain mold and downy mildew in a mini-core collection of sorghum germplasm. Plant Disease 94, 439-444.

22. Steel, R.G. D., Torrie J. H. and Dickey, D. A. (1997). Principles and procedures of statistics; a biometrical approach, 3rd edn. McGraw-Hill, Boston.

23. Thakur R. P. and Mathur K. (2002). Downy mildews of India. Crop Protection 21, 333-345.

24. Thakur, R. P. and Pande, S. (1995). Genetic management of major fungal pathogens of sorghum. Pages $315-326$ in Detection of plant pathogens and their management (Verma, J.P., Varma, A., and Kumar, D. eds.). New Delhi, 110 041, India: Angkor Publishers (P) Ltd.

25. Thomas, M. D. (1992). Sorghum diseases in Western Africa. Pages 25-29 in: Sorghum and Millets Diseases: A Second World Review. W. J. A. de Milliano, R. A. Frederiksen, and G. D. Bergston, eds. ICRISAT, Patancheru, India.

26. Tongco, M. D. (2007). Purposive Sampling as a Tool for Informant Selection. A Journal of Plant, People and Applied Research Ethnobotany Research and Applications, 1-12.

27. UBOS. (2010). Uganda Census of agriculture 2008/ 2009.Volume IV: Crop Area and Production Report. 54pp.

28. Wang, M. L., Ryley, M. and Meinke, H, (2000). Prediction of sorghum downy mildew risk in Australia using daily weather data. Australasian Plant Pathology, 29(2):108-119.

29. Ward, J. M. J., Laing, M. D., and Rijkenberg, F. J. (1997). Determining incidence and severity if downy mildew disease in Maize and Sorghum. Plant Disease 81:41-48.

30. Ward, J. M. J., Stromberg E. L., Nowell, D. C. and Nutter, Jr. F. (1999). Grey leaf spot: A disease of global importance in maize production. Plant Disease 83: 884 - 895.

31. Wortmann, C. S. and Eledu, C. A. (1999). Uganda's agro-ecological zones: A guide for policy makers. Uganda; CIAT Kampala. 